\title{
Blastoid Variant Mantle Cell Lymphoma
}

National Cancer Institute

\section{Source}

National Cancer Institute. Blastoid Variant Mantle Cell Lymphoma. NCI Thesaurus. Code C7229.

An aggressive mantle cell lymphoma characterized by the presence of neoplastic Blymphocytes resembling lymphoblasts. 